\title{
The Brain in Schizotypal Personality Disorder: A Review of Structural MRI and CT Findings
}

\section{Citation}

Dickey, Chandlee C., Robert W. McCarley, and Martha E. Shenton. 2002. "The Brain in Schizotypal Personality Disorder: A Review of Structural MRI and CT Findings." Harvard Review of Psychiatry 10 (1) (January): 1-15. doi:10.1080/10673220216201.

\section{Published Version}

doi:http:10.1080/10673220216201

\section{Permanent link}

http://nrs.harvard.edu/urn-3:HUL.InstRepos:28520171

\section{Terms of Use}

This article was downloaded from Harvard University's DASH repository, and is made available under the terms and conditions applicable to Other Posted Material, as set forth at http:// nrs.harvard.edu/urn-3:HUL.InstRepos:dash.current.terms-of-use\#LAA

\section{Share Your Story}

The Harvard community has made this article openly available.

Please share how this access benefits you. Submit a story.

\section{Accessibility}




\title{
The Brain in Schizotypal Personality Disorder: A Review of Structural MRI and CT Findings
}

\author{
Chandlee C. Dickey, MD, Robert W. McCarley, MD, and Martha E. Shenton, MD \\ From the Clinical Neuroscience Division, Laboratory of Neuroscience, Department of Psychiatry, \\ VA Boston Healthcare System, Boston, Mass. (Drs. Dickey, McCarley, and Shenton); the Division \\ of Behavioral Neurology, Departments of Neurology and Psychiatry (Dr. Dickey), and the Surgical \\ Planning Laboratory, MRI Division, Department of Radiology (Dr. Shenton), Brigham and Women's \\ Hospital, Boston, Mass; and the Department of Psychiatry, Harvard Medical School, Boston, Mass. \\ (Drs. Dickey, McCarley, and Shenton).
}

\section{Abstract \\ Studies of schizotypal personality disorder (SPD) are important because the condition is genetically related to schizophrenia and because data accumulating to confirm its biological underpinnings are challenging some traditional views about the nature of personality disorders. This review of 17 structural imaging studies in SPD indicates that individuals with this disorder show brain abnormalities in the superior temporal gyrus, parahippocampus, temporal horn region of the lateral ventricles, corpus callosum, thalamus, and septum pellucidum, as well as in total cerebrospinal fluid volume, similar to those seen in persons with schizophrenia. Differences between SPD and schizophrenia include lack of abnormalities in the medial temporal lobes and lateral ventricles in SPD. Whether the normal volume, and possibly normal functioning, of the medial temporal lobes in individuals with SPD may help to suppress psychosis in this disorder remains an intriguing but still unresolved question. Such speculation must be tempered due to a paucity of studies, and additional work is needed to confirm these preliminary findings. The imaging findings do suggest, however, that SPD probably represents a milder form of disease along the schizophrenia continuum. With further clarification of the neuroanatomy of SPD, researchers may be able to identify which neuroanatomical abnormalities are associated with the frank psychosis seen in schizophrenia.}

\begin{abstract}
Although schizophrenia was once considered the "graveyard of neuropathologists," 1 recent neuroimaging techniques have radically changed this view. Early studies using computerized tomography (CT) were pivotal in demonstrating ventricular abnormalities in the disorder but did not provide the resolution required to document alterations in regions with unclear boundaries such as the amygdala and various thalamic nuclei. With the advent of magnetic resonance imaging (MRI), these latter brain regions of interest have been evaluated in schizophrenia and found to be abnormal. In recent comprehensive reviews ${ }^{2}, 3$ of MRIdocumented morphological brain abnormalities in schizophrenia, most brain regions studied showed neuroanatomical alteration compared with the same regions in healthy controls. Nonetheless, a convergence of findings suggested that the major locus for brain abnormalities was the temporal lobe; fewer studies reported abnormalities in the lateral ventricles, prefrontal cortex, inferior parietal cortex, basal ganglia, thalamus, corpus callosum, or septum pellucidum.2,3 Note that, although many regions are involved in schizophrenia, they do not appear to be equally affected, and the temporal lobe regions are the most severely altered. (For
\end{abstract}

(C) 2002 President and Fellows of Harvard College

Reprint requests: Martha E. Shenton, PhD, VA Boston Healthcare System, Psychiatry 116A, 940 Belmont St., Brockton, MA 02401 (martha_shenton@hms.harvard.edu). 
a recent review of MRI findings in schizophrenia and a discussion comparing the various brain regions, see Shenton and colleagues.2)

In many cases, however, these MRI findings are difficult to interpret, given the possible confounding effects of the chronicity of the psychotic illness and the medications used to treat it. Although the definition of a personality disorder4 requires that a person experience distress, the stress of chronic psychosis as seen in schizophrenia is arguably more relentless. McEwen and Margarinos ${ }^{5}$ have demonstrated that increased stress-induced adrenal cortisol release, along with excitatory amino acids, may result in atrophy of the hippocampal CA3 region. Such atrophy may help to explain some of the medial temporal lobe findings in schizophrenia (see section on temporal lobe structures, below).

Medications can also affect brain morphology. Chakos and colleagues ${ }^{6,7}$ compared the volume of the basal ganglia in patients taking traditional and atypical antipsychotics and found that the traditional antipsychotics increased caudate volume more than did the atypical medications. Other possible effects of medication on brain morphology have been reported for superior temporal gyrus volume. ${ }^{8}$ In addition, a recent animal model ${ }^{9}$ demonstrated increased volume $^{2}$ and glial density in the prefrontal cortex with chronic exposure to conventional neuroleptics. The effect of anticholinergics, benzodiazepines, and anticonvulsants on specific brain regions has been less extensively examined.

One way to avoid the possible confounding effects of medication is to study patients during a first episode of schizophrenia, before they are treated with medications, ${ }^{10-15}$ as well as to investigate at-risk populations, ${ }^{16}$ including first-degree relatives of individuals with schizophrenia. ${ }^{17-23}$ An alternative approach is to study other populations presumed* to have similar genetic vulnerability, such as patients with schizotypal personality disorder (SPD). Our review will focus on CT and MRI structural imaging studies of persons with SPD.

SPD is characterized by difficulties with social interaction and language, together with odd behavior and magical thinking. Because individuals with this disorder are not considered psychotic, they have generally not been prescribed medications. Nonetheless, persons with SPD and those with schizophrenia have a similar genetic predisposition, as suggested by multiple family studies ${ }^{24,27-31}$ reporting that 6-7\% of individuals diagnosed with schizophrenia have a first-degree relative with SPD. Similarly, first-degree relatives of persons with SPD have a $6.9 \%$ chance of developing schizophrenia. ${ }^{27}$

In an early epidemiological study conducted in Denmark, Kety and colleagues ${ }^{29}$ found that the data supported the notion of a commonality between schizophrenia and schizophrenia-like disorders, and they grouped these conditions into the "schizophrenia spectrum disorders." This work was followed by Kendler and colleagues' Roscommon County family studies, ${ }^{27,30}$ which further supported the spectrum concept and encouraged the use of other research tools to define the phenotypic similarities between SPD and schizophrenia.

Other methodologies such as neurochemical analyses, behavioral studies, and neuropsychological and evoked-potential measures have also shown abnormalities in SPD that are similar to what has been demonstrated in schizophrenia. ${ }^{32}$ These include elevated homovanillic acid levels, ${ }^{33,34}$ aberrant eye-tracking, ${ }^{35-38}$ reduced prepulse inhibition, ${ }^{39}$ cognitive deficits, $40^{-} 43$ and electrophysiological abnormalities. $44^{-48}$ One hypothesis that attempts to incorporate findings from these various methodologies has been proposed by Siever (personal communication), who stated that the relative sparing in terms of symptoms and

\footnotetext{
*,Presumed," since the underlying defective gene-gene interactions in schizophrenia have yet to be elucidated, although population studies have supported the contention that schizophrenia and SPD share a common genetic diathesis (see below). ${ }^{24-} 28$
} 
biological abnormalities in SPD compared with schizophrenia may be due to the fact that hypodopaminergic function emanates from the basal ganglia and extends to the frontal lobes. These projections may be "neuroprotective" to other regions such as the frontal lobes. ${ }^{32,49}$ Structural MRI studies of the basal ganglia and frontal lobes as well as functional studies examining dopaminergic function are needed to test this hypothesis further.

Another impetus for studying SPD, in addition to the disorder's close genetic and biological ties with schizophrenia, is the importance of such research for the conceptualization of personality disorders. More specifically, personality disorders have traditionally not been thought to have a neurological basis. Now a wealth of data from multiple sources is radically challenging this view (see the studies cited in the previous paragraph). Moreover, with the neuroanatomical basis of SPD becoming more clearly established, investigations of the biological underpinnings of SPD may be a useful model to apply to other personality disorders.

The critical question that we ask, and seek to answer, in this review is: Do the imaging data support the notion that SPD is a less severe version of schizophrenia, or is it a distinct disorder? If the former, might we expect that persons with SPD will have fewer neuroanatomical abnormalities, and therefore less-severe clinical symptoms, than do individuals with schizophrenia? If the data support the idea that SPD is a less penetrant form of schizophrenia, then the next question concerns what abnormalities are present in schizophrenia but absent in SPD. Answers to this last question need to be examined in future studies and may help to direct attention to strategies for preventing the development of schizophrenia.

We performed a Medline search in February 2001 for English-language articles including the key words schizotypal personality disorder, schizophrenia, relatives, computerized tomography, and magnetic resonance imaging. We found and reviewed 17 studies. We began with investigations in which subjects met full DSM criteria for SPD, then continued with studies in which subjects had some of the features of SPD but did not meet the full criteria, reports of children with symptoms consistent with SPD, and finally other studies (i.e., reports of persons with SPD and schizophrenia analyzed together, or of individuals with SPD who have family members with schizophrenia). This organization reflects the different strategies used by researchers to enlist subjects with SPD for their studies. Such strategies include recruiting families of probands with schizophrenia, recruiting patients from clinics, recruiting community dwellers by means of newspaper advertisements, and recruiting college students who score high on scales of psychopathology thought to tap cognitive manifestations of SPD. Diagnostic criteria have also differed and range from meeting five out of the nine required DSM-IV criteria, to having some features of schizotypy derived by diagnostic impression during clinical interview, to scoring high on scales of psychopathology.

We included all 17 studies in our review, even though some included very few patients with SPD or SPD-like pathology. Table 1 provides a summary of these studies.

\section{OVERVIEW}

Two important changes have occurred over time in brain morphology studies of individuals with SPD. First, CT techniques have gradually given way to MRI, which has allowed the investigation of more regions and with finer neuroanatomical resolution (including differentiation between gray and white matter). Second, researchers have gone from examining subjects with some features of schizotypy to studying persons determined through semistructured interviews to meet full DSM criteria for SPD. This change can been seen in Table 1, where it is clear that the majority of recent studies use MRI and involve subjects meeting full criteria for SPD. 
All eight of the MRI studies that analyzed the data for subjects with full criteria separately have emanated from two centers, Mt. Sinai School of Medicine ${ }^{49-52}$ and Harvard Medical School. 53-55 (Note that in 1992 and 1994 researchers from the University of Pennsylvania56,57 used CT to examine a cohort of subjects who met full criteria for SPD, considered under the category of subjects at high risk for schizophrenia [all had mothers with the disorder].) This illustrates not only the difficulty in recruiting this important subject population but also the fact that different laboratories employ different approaches for understanding the intrinsic morphological abnormalities of the brain found in the schizophrenia spectrum disorders. Importantly, however, nine of the 17 studies were published since 1998, suggesting a marked increase in interest in this topic.

\section{STUDIES OF SUBJECTS WHO MEET FULL CRITERIA FOR A DIAGNOSIS OF SPD}

Two laboratories investigating SPD have used individuals who meet full DSM criteria for the diagnosis of SPD. The two laboratories have employed distinctly different recruitment procedures, however. The first laboratory, at Mt. Sinai School of Medicine, has recruited its subjects from local inpatient and outpatient units. Some of these individuals have received medications, including neuroleptics. Our laboratory at Harvard Medical School and the Veterans Affairs Boston Healthcare System, by contrast, has recruited subjects from the community by means of newspaper ads and posted fliers so as to avoid the potential confounding effects of medication. The use of such disparate approaches may have resulted in the sampling of quite different populations. This fact, plus differences between the clinical assessment protocols in the two laboratories, makes direct comparisons between the study populations difficult. The Mt. Sinai cohort, for example, may include subjects with either moreserious symptoms or a greater proportion of positive symptoms, leading them to attend a clinic and be prescribed neuroleptic medications; our cohort may include subjects with a greater proportion of negative symptoms, or with fewer or more-attenuated symptoms. All of this is conjecture, however, since neither group has reported measures of positive and negative symptoms. In addition, neither group of researchers has discussed the potential issue of high Axis I and Axis II comorbidity, which has been described by McGlashan. ${ }^{58}$ This may be an important focus for future work on the biological basis of SPD. These different approaches may be complementary in that they may help to elucidate how clinical features affect brain morphology. Note that, as with other studies included in this review, the number of subjects studied in these laboratories is limited, and within a laboratory, samples have partially overlapped. This reflects the difficulties inherent in recruiting subjects with SPD. However, since researchers are just beginning to understand the neuroanatomy of SPD, extensive study of various brain regions in a limited number of subjects may be a prudent approach.

Below, we review findings from Mt. Sinai on the thalamus and corpus callosum. We then review findings from our laboratory on cerebrospinal fluid (CSF), gray and white matter, temporal lobe structures, and the cavum septi pellucidi, and finally the findings from both laboratories on the lateral ventricles.

\section{Mount Sinai Group: Clinic-Based Studies}

Thalamus-The thalamus is the major relay station of the brain; it consists of multiple nuclei and their connections to cortical regions (i.e., mediodorsal nuclei with the prefrontal cortex, and anterior and midline nuclei with limbic and paralimbic structures59). Due to these interconnections, the thalamus is considered by some to be key to the understanding of schizophrenia.60 
The first study of thalamic volume in subjects with SPD, conducted by Hazlett and colleagues,

51 showed no differences in thalamic volume or thalamus:brain ratio between patients with SPD and controls but did show differences in shape. Patients with SPD had fewer pixels in the right mediodorsal nucleus and patients with schizophrenia had fewer pixels in the left anterior region than did controls. In a second component of the study, the investigators determined with positron emission tomography that patients with schizophrenia had diminished metabolism in the mediodorsal nucleus bilaterally compared with SPD patients and comparison subjects.

To refine these findings further, Byne and colleagues ${ }^{52}$ examined the pulvinar and mediodorsal nuclei of the thalamus in a subset of the subjects. They reported that, compared with controls, both the patients with SPD and those with schizophrenia had reduced pulvinar nuclei, but the patients with schizophrenia had the additional abnormality of reduced mediodorsal nuclei. Various subdivisions of the pulvinar are involved in relaying sensory inputs to primary visual and auditory sensory areas, ${ }^{59}$ to the prefrontal cortex,${ }^{52}$ and to the temporoparietal heteromodal association cortex..$^{52,61}$ There are a few reports of damage to this region resulting in language disturbances. ${ }^{51,60}$ Thus, these nuclei may be critically involved in the processing and integration of visual and auditory information, and damage could hypothetically result in misperceptions.

Taken together, these results suggest that frontolimbic/thalamic connectivity may be different in SPD than in schizophrenia, and this may, in part, contribute to the differences in the clinical symptoms in the two disorders. Such a possibility is particularly interesting, given the current interest in thalamic connections and, as proposed by Andreasen and others, ${ }^{60}$ their possible central role in the production of these conditions.

Corpus callosum-The corpus callosum is the major interhemispheric fiber pathway. One of the theories of the etiology of schizophrenia62 involves a failure of interhemispheric communication. As a result, the corpus callosum has been the subject of 27 investigations; 17 of these have reported abnormalities.2 In the only study to examine corpus area and shape in SPD, Downhill and colleagues ${ }^{49}$ reported that the genu of the corpus was larger in patients with SPD than in those with schizophrenia or control subjects, whereas the posterior corpus was largest in controls, second largest in patients with SPD, and smallest in patients with schizophrenia. (The difference in the latter measure between SPD patients and schizophrenia patients was not statistically significant, however.) Furthermore, these investigators found that the shape differences were consistent with the differences in corpus area. They concluded that these area and shape abnormalities of the corpus may lead to poor interhemispheric connectivity and could be responsible for the improper reality testing found in the schizophrenia spectrum disorders.

\section{Our Laboratory: Community-Based Studies}

CSF, gray, and white matter-In many studies of patients with schizophrenia, there appears to be an abundance of CSF, whether measured in the ventricles, in the sulci, or as total CSF volume. ${ }^{2,3}$ In our sample of individuals with SPD, we demonstrated increased CSF volume that was not attributable to lateral ventricle enlargement. We also examined total gray matter volume and found no difference between persons with SPD and normal controls. However, when the cortical gray matter was more carefully delineated with the elimination of the subcortical structures and the cerebellum, we found a trend toward reduced cortical gray matter in persons with SPD compared with controls. ${ }^{55}$ We found no difference in white matter between the two groups.

Temporal lobe structures-Interest in temporal lobe structures in schizophrenia stems from the critical role of these structures in language and auditory processing and the observation 
that language abnormalities and auditory hallucinations are among the hallmarks of this disorder. Of note, many independent research laboratories investigating schizophrenia have reported abnormalities in temporal lobe structures, $2,3,63^{-67}$ including the superior temporal gyrus (STG), parahippocampal gyrus, and amygdala-hippocampal complex. The volumes in these regions have also been correlated with cognitive and clinical symptoms including formal thought disorder and auditory hallucinations, as well as with verbal memory problems. ${ }^{62,68}$ The amygdala, more specifically, may be involved in the attaching of emotional relevance, particularly to visual stimuli including emotional facial expressions;69 in general arousal and other basic functions including sleep, feeding, and sexual activities;68 and in memory. ${ }^{68}$

Our own laboratory ${ }^{70}$ has reported reductions in gray matter volume in the STG, amygdala, hippocampus, and parahippocampal gyrus in persons with schizophrenia, and we have extended this work to patients with first-episode psychosis ${ }^{71}$ and individuals with SPD. We applied the methodology of our previous studies in schizophrenia to a group of individuals with SPD recruited from the community by means of newspaper advertisements. We predicted that we would see similar, but more-attenuated, volume reduction in the subjects with SPD. We found such subjects to have selective reduction of the left STG gray matter and parahippocampal asymmetry.54 In an attempt to refine the STG results, we examined two of its main components, Heschl's gyrus and the planum temporale, 72 and found the former to be reduced. In addition, we found that subjects with SPD exhibited formal thought disorder.54 This was intriguing, since reduced STG gray matter is one of the most robust findings in schizophrenia (all of the 12 studies examining this found volume reduction2), and parahippocampal asymmetry has been shown postmortem to be abnormal in persons with schizophrenia.73 This study demonstrating partial—but not complete—replication suggested that perhaps, at least in this region, there is a relationship between volume affected and clinical severity.

Cavum septi pellucidi-The septum pellucidum is a membrane formed in utero by two leaflets that fuse secondary to pressure of the growing hippocampus and corpus callosum. Space remaining when the closure is incomplete is termed "cavum septi pellucidi"; such a space is seen in $15 \%$ of healthy controls 52 at 6 months. ${ }^{53}$ The presence of a large cavum septi pellucidi has been noted in schizophrenia (11 out of 12 studies reported abnormalities). ${ }^{2}$ One study53 has examined this neurodevelopmental abnormality in patients with SPD, and it found a prevalence of $27 \%$. These data suggest that SPD and schizophrenia probably have a neurodevelopmental component to their etiology.

\section{Clinic- and Community-Based Studies: Lateral Ventricle Findings}

The two laboratories have each examined the lateral ventricles in patients with SPD. They produced slightly different results in the anterior and temporal horns, possibly due to different demographic variables.

Historically, enlarged lateral ventricles have been one of the most common findings in the schizophrenia literature: $78 \%$ of the 55 MRI2 studies (as well as 75\% of the CT studies2) examining this region showed larger lateral ventricles in persons with schizophrenia than in controls. However, neither the Mt. Sinai group (first with CT74 and then with MRI50) nor our group55 has found a statistically significant difference in total lateral ventricle volume between individuals with SPD and controls. Thus, in this region there appears to be a difference between schizophrenia and SPD: persons with SPD are less affected than are those with schizophrenia.

Subtle differences may exist between persons with SPD and healthy controls in particular regions of the lateral ventricles, however. In an evaluation of clinic-based SPD patients at Mt. Sinai, Buchsbaum and coworkers ${ }^{50}$ reported that the left anterior and temporal horns in these individuals were larger than those in age- and sex-matched normal controls but significantly 
smaller than those in patients with chronic schizophrenia. This contrasts with what our laboratory has shown in our community-based sample, in which we reported no difference.

55 Therefore, although both groups report no statistically significant difference between persons with SPD and controls, the Mt. Sinai study included the additional feature of comparing such volumes with those of schizophrenia patients and demonstrated a continuum among the three groups on this measure.

These two studies were similar in that they both involved subjects meeting full criteria for SPD, but they differed in demographic variables. Left- and right-handed males and females were included in Buchsbaum and colleagues' investigation, ${ }^{50}$ whereas only right-handed males were included in Dickey and coworkers' study. ${ }^{55}$ Perhaps the greatest difference in the samples, however, results from the method of recruitment-clinic versus community. Subjects in a clinic-based sample may have more-severe SPD symptoms than do those in a communitybased one; they may also have fewer negative symptoms such as social anxiety. The issue of high Axis I and Axis II comorbidity, which has been described in SPD $^{58}$ but is not addressed in these publications, may also be important in deciphering the findings. In addition, pharmacological treatment of SPD patients could be playing a role in clinic-based samples. These variables may be key in understanding the subtle differences in the findings concerning the anterior and temporal horns.

In summary, these two MRI studies of subjects who met full criteria for SPD did not show enlarged lateral ventricles. This may suggest that in individuals with pure SPD this region is spared the abnormalities typically seen in persons with schizophrenia. Subsequent studies to examine the lateral ventricles either have analyzed SPD patients together with schizophrenia patients or have not used subjects clearly diagnosed with SPD (see below). One tentative conclusion, therefore, is that enlargement of the lateral ventricles is not a feature of SPD, and the presence of enlarged ventricles in schizophrenia may be a morphological index of clinical severity.

\section{OTHER STUDIES}

\section{Studies of Subjects with Schizotypal Features Who Meet Some but Not All Criteria for a Diagnosis of SPD: Frontotemporal Area}

One approach to understanding the schizophrenia spectrum disorders is to study individuals who do not meet criteria for a particular disorder but who nonetheless have some of the features of that disorder. This approach is best exemplified by Raine and coworkers, 75 who examined 17 subjects who scored high on scales of schizotypal features but were not assessed using DSM criteria. These individuals were employees of local hospitals and other work settings. Excluded from the pool of perspective subjects were physicians and other workers expected to have high social class and a high level of education. In this study high degrees of schizotypy were found to be significantly associated with reduced left prefrontal area and with left and right prefrontal:temporal area ratios. The prefrontal cortex is involved in impulse inhibition, assessing the behavioral relevance of stimuli, using working memory while shifting sets, making judgments, and planning. It has vast interconnections with most other sections of the cortex and can influence the activation or de-activation of those areas. ${ }^{59}$ Unfortunately, the imaging protocol was performed on a machine with low magnetic field strength $(0.15 \mathrm{~T}$, as opposed to the $1.5 \mathrm{~T}$ often used), and only one slice was used to determine prefrontal and temporal areas for each subject. Nonetheless, this early study suggested that persons with some schizotypal features may have aberrations in the prefrontal and temporal cortices- areas that have been shown to be abnormal in individuals with schizophrenia.

An excess of schizotypal traits in subjects with a sex chromosome aneuploidy (SCA) was documented in a recent thesis. ${ }^{76}$ To follow up on this observation, Warwick and 
colleagues77 studied individuals with SCA and some features of schizotypy. Using MRI to examine multiple brain regions including the prefrontal cortex, they detected no abnormalities. Unfortunately, data for the subjects with SCA and many features of schizotypy were not analyzed separately from data for those with SCA alone.

Given the paucity of prefrontal studies examining subjects who have been clearly diagnosed with SPD, no firm conclusions can be drawn for this brain region.

\section{A Study of Children at Risk for Developing SPD or Schizophrenia: Amygdala, Temporal Cortex, and Corpus Callosum}

In the only relevant study of children, Hendren and colleagues ${ }^{78}$ reported that 8 - to 12 -yearolds with symptoms of either SPD or schizophrenia showed reduced amygdala and temporal cortex volumes and reduced corpus callosum area, similar to what has been shown in schizophrenia. ${ }^{2,3}$ The authors suggested that the occurrence of abnormalities at a young age is the result of genetic or environmental events occurring in utero and altering neurodevelopment; they did not explore other possible etiologies, such as postnatal stress. Hendren and coworkers did not demonstrate enlarged lateral ventricles, as has been shown in subjects meeting full criteria for SPD. ${ }^{50,55}$ Instead, they hypothesized that enlarged ventricular volume may represent disease progression in schizophrenia, a speculation shared by others, ${ }^{79,80}$ but because the study was cross sectional, their data did not address that issue directly. Due to the subjects'young age, the investigators were unable to make definitive distinctions between SPD and schizophrenia, so subject groups were not analyzed separately. As suggested by the authors, it will be interesting to follow these children and retrospectively review their scans to determine whether the children who subsequently developed SPD had quantitatively fewer abnormalities than did those who subsequently developed schizophrenia.

\section{A Study Analyzing Patients with SPD and Those with Schizophrenia Together: Ventricles}

In a hospital-based study of patients with SPD or schizophrenia who also had prodromal symptoms of obsessive-compulsive disorder (OCD), persons with nonpsychotic OCD, and normal controls, Kurokawa and coworkers ${ }^{81}$ examined MRIs to determine whether the presence of enlarged ventricles might promote the early detection of SPD or schizophrenia in persons who early in the course of the illness show symptoms of OCD. They found that the patients who had developed SPD or schizophrenia had larger ventricles than did those with OCD alone. They concluded that patients with OCD symptoms and enlarged ventricles on MRI may be at risk for later developing one of the schizophrenia spectrum disorders. They did not analyze data for the SPD patients separately, however, probably due to the small sample size $(n=4)$. Conclusions about ventricular size in SPD cannot be drawn from this study, since the subjects with schizophrenia may have been driving the findings.

\section{Studies of Patients with SPD Who Have First-Degree Relatives with Schizophrenia: Ventricles}

The Mt. Sinai group, in search of genetic markers common to schizophrenia spectrum disorders, has studied family pedigrees of probands with schizophrenia. Within these families, some members have been affected by SPD. Shihabuddin and colleagues ${ }^{82}$ studied a family with the linkage marker for such disorders on the short arm of chromosome 5(5p14.1-13.1). Eleven family members (of whom three had schizophrenia and two had SPD) underwent CT to determine whether there was a relationship between the presence of the marker and brain abnormalities. All of the affected members and one unaffected member carried the marker allele. These six individuals had enlarged lateral ventricles and an enlarged ventricle:brain ratio (VBR), whereas the remaining unaffected members did not. 
Silverman and colleagues ${ }^{83}$ have shown increased VBR in persons with SPD or schizophrenia in a larger group of families. In this study, however, the researchers lumped the individuals with SPD together with family members who had four of nine criteria for the disorder but not full-blown SPD. How the persons with full criteria differed from those with partial criteria was not detailed. Nonetheless, the investigation suggested a relationship between the genetic loading and brain structure.

Prior to the publication of DSM-III, persons with features consistent with SPD (for example, subtle thought disorder, social isolation, magical thinking) were classified as having borderline schizophrenia. ${ }^{84}$ Today, many of these subjects would be reclassified by DSM-IV criteria as having SPD. In an early CT study of offspring of mothers with schizophrenia, Schulsinger and coworkers 84 found that the offspring with schizophrenia had enlarged third ventricles and an increased VBR, whereas the mentally healthy offspring had normal ventricles, and those with borderline schizophrenia had the smallest ventricles. This is the only study in our review that reported smaller ventricles in subjects with an SPD-like disorder than in controls. In addition, the offspring with schizophrenia had experienced more obstetrical complications than had either of the other two groups. These authors 84 suggested the "diathesis-stress" model for interpreting the data-that is, that "schizophrenia is the result of deleterious environmental influences acting on a genetic predisposition."

In a second CT study of offspring of mothers with schizophrenia, Cannon and colleagues57 found that the offspring suffering from SPD or schizophrenia had enlarged sulci, but only those with schizophrenia had enlarged ventricles. (The study also included offspring of unaffected mothers. Some of these offspring had psychiatric disorders, and some did not. The four offspring with SPD who had unaffected mothers were not analyzed separately.) These researchers concluded that the offspring with the more-severe disorder, schizophrenia, had more morphological abnormalities (sulcal and ventricular enlargement), whereas those with SPD had sulcal enlargement alone. Previously these researchers ${ }^{56}$ had demonstrated that offspring of mothers with schizophrenia (healthy, with SPD, or with schizophrenia) had enlarged third ventricles, but unfortunately they did not perform analyses comparing the three groups.

\section{DISCUSSION}

It is difficult to reach conclusions from such a limited number of studies composed of small sample sizes and subjects with disparate characteristics. Nonetheless, from studies with subjects who meet full criteria for SPD, it appears that individuals with SPD may have reduced gray matter of the superior temporal gyrus, asymmetry of the parahippocampus, abnormalities in thalamic shape and pulvinar volume, larger sulci, abnormalities in the shape of the corpus callosum, and a high prevalence of large cavum septi pellucidi. Each of these potential abnormalities has been well documented in schizophrenia. $2{ }^{3}$ In most of the studies, however, the subjects with SPD do not have all of the abnormalities that might be present in schizophrenia. For example, persons with SPD have reduced superior temporal gyrus volumes and parahippocampal asymmetry but not the frank parahippocampal volume differences or differences in other medial temporal lobe structures such as the hippocampus and amygdala that are found in schizophrenia (see above). Also, from the studies done to date, lateral ventricles appear to be normal.

The specific pathogenesis of these morphometric alterations in SPD cannot be determined from the studies reviewed. For example, one cannot deduce whether the abnormalities are a direct result of neurodevelopmental genetic programing, whether they are a result of distal abnormalities causing deafferentation, or whether they represent a decrease in interneurons. 
Byne and colleagues, ${ }^{52}$ in their discussion of thalamic abnormalities, proposed the possibility of different etiologies for different nuclei within the thalamus.

To determine whether the additional regions affected in schizophrenia are critical for the production of frank psychosis (i.e., whether they are also present in affective disorder with psychosis) or are inherent to schizophrenia, data from our laboratory comparing affective disorder with psychosis is informative. Table 2, a comparison among SPD, first-episode schizophrenia, and first-episode psychotic affective disorder, ${ }^{71}$ shows that the development of psychosis may require abnormalities in the medial temporal lobe structures. This is in contrast to the involvement of the superior temporal gyrus, the increase in sulcal CSF, and the decrease in cortical gray matter found in both SPD and schizophrenia, but not in first-episode psychosis. These patterns of abnormalities suggest that the superior temporal gyrus may be critical in the schizophrenia spectrum disorders.

To return to our earlier question of whether SPD should be considered a distinct disorder or a subset of schizophrenia, we believe that the CT and MRI data produced so far cannot fully separate the two conditions. To date, there has been no definitive report of an SPD abnormality that has not been shown in schizophrenia. ${ }^{\dagger}$ In fact, one of the strategies of SPD research is to examine brain regions that have been found to be abnormal in schizophrenia to determine whether they may represent abnormalities fundamental to the schizophrenia spectrum disorders or to psychosis. Once other brain regions are examined, additional abnormalities may be found. However, based on the available literature, one can conclude that not all the abnormalities found in schizophrenia are found in SPD. For example, medial temporal lobe structures are normal in SPD. ${ }^{54}$ Therefore, SPD may be considered to represent an attenuated form of schizophrenia.

The implication of these findings is that individuals with SPD are comparatively spared in some brain regions while those with schizophrenia are relatively afflicted, despite possibly similar genetic diatheses. It may be, however, that this genetic continuum can result in some subjects having more of a critical genetic load and others having less. Additionally, subtle in utero differences such as lower incidence of exposure to influenza virus—or less stress-induced steroid release-in persons with SPD than in those with schizophrenia may account for the differences in the development of the two disorders. Finally, as these individuals age, repeated environmental stressors may have an additional impact on the progression of both SPD and schizophrenia. How sparing or affliction occurs is critical to determine in future studies.

We believe that SPD represents part of the continuum of clinical symptoms observed in the schizophrenia spectrum and involves some of the same morphological abnormalities. Conservatively speaking, however, the available CT and MRI data cannot rule out the possibility that SPD is a distinct disorder, although this possibility seems unlikely. One primary strategy of SPD research is to examine brain regions that have been found to be abnormal in schizophrenia to determine whether or not they are also observed in SPD or are a nonspecific concomitant of psychosis. One example of the separation between SPD and psychosis is demonstrated by the finding that medial temporal lobe structures (the amygdala and hippocampus) are abnormal in first-episode schizophrenia and in first-episode psychosis ${ }^{71}$ but not in SPD.54

\footnotetext{
$\dagger$ There are two possible exceptions. Downhill and colleagues 49 reported corpus callosum shape differences in certain regions in persons with SPD. The corpus has been shown to be abnormal in schizophrenia, ${ }^{2}$ although perhaps in slightly different regions. Also, Hazlett and colleagues ${ }^{51}$ found fewer pixels in the region of the right mediodorsal nucleus in patients with SPD than in those with schizophrenia or normal controls.
} 


\section{FUTURE DIRECTIONS}

Clearly more studies are necessary to investigate the neuroanatomy of SPD. Persons who meet full criteria for SPD need to be evaluated, and this population, although difficult to tap, is important to our understanding of which brain abnormalities are inherent to the schizophrenia spectrum and which are due to the ravages of schizophrenia and its treatments—or perhaps to other prenatal or environmental stresses. The relationship among genetic load, pre- and postnatal environmental factors, and morphological abnormalities in the development of schizophrenia is far from clear. Nonetheless, understanding the interaction of these factors is critical for understanding the pathogenesis of schizophrenia and potential avenues for intervention.

This review focused on CT and structural MRI findings in SPD. Morphological studies can describe volumes, shapes, and anatomical patterns but cannot address the critical question of the functional capacity of the structures. To date, no functional MRI (fMRI) studies of SPD have been published. As more laboratories move toward fMRI and begin to elucidate the functional anatomy of this disorder, it will be important to discover how individuals with SPD differ from those with schizophrenia in the realms of attention, language processing, and emotional processing/expression, where some of the core abnormalities in the schizophrenia spectrum are seen. This complementary coupling of morphometric and functional studies can then begin to address the relationship between anatomy and clinical phenomena. For example, if one believes that magical ideation and certain delusions represent clinical phenomena along a continuum of severity, then fMRI experiments involving subjects with SPD or schizophrenia who are experiencing magical ideation or delusions, respectively, may help to sort out the anatomy involved in those two phenomena. Such an experiment may point to specific areas of functional impairment in the brains of these individuals. However, interpreting findings of a reduced fMRI signal is difficult without knowing underlying structural volumes. In addition, understanding how persons with a schizophrenia spectrum disorder process information may be invaluable for family members coping with these devastating conditions.

\section{Acknowledgments}

Supported, in part, by a VA Career Development Award (Dr. Dickey); by grants from the National Institute of Mental Health, including MH 01110 (Dr. Shenton), MH 50740 (Dr. Shenton), MH 52807 (Dr. McCarley), and MH40799 (Dr. McCarley); and by VA Merit Awards (Drs. Shenton and McCarley).

We wish to thank Drs. Ferenc Jolesz and Ron Kikinis, of the Brigham and Women's Hospital Surgical Planning Laboratory, for their continuing support of our neuroimaging efforts; Marie Fairbanks, for her administrative support; and Sarah Toner, for her literature search and for her assistance in producing the manuscript.

\section{REFERENCES}

1. Plum F. Prospects for research on schizophrenia, 3: Neurophysiology: neuropathological findings. Neurosci Res Program Bull 1972;10:384-388. [PubMed: 4663816]

2. Shenton ME, Dickey CC, Frumin M, McCarley RW. A review of MRI findings in schizophrenia. Schizophr Res 2001;49:1-52. [PubMed: 11343862]

3. McCarley RW, Wible CG, Frumin M, Hirayasu Y, Levitt JJ, Fischer IA, et al. MRI anatomy of schizophrenia. Biol Psychiatry 1999;45:1099-1119. [PubMed: 10331102]

4. American Psychiatric Association. Diagnostic and statistical manual of mental disorders. 4th ed.. Washington, DC: American Psychiatric Association; 1994.

5. McEwen BS, Margarinos AM. Stress effects on morphology and function of the hippocampus. Ann NY Acad Sci 1997;821:271-284. [PubMed: 9238211]

6. Chakos MH, Lieberman JA, Bilder RM, Borenstein M, Lerner G, Bogerts B, et al. Increase in caudate nuclei volumes of first-episode schizophrenic patients taking antipsychotic drugs. Am J Psychiatry 1994;151:1430-1436. [PubMed: 7916539] 
7. Chakos MH, Lieberman JA, Alvir J, Bilder R, Ashtari M. Caudate nuclei volumes in schizophrenic patients treated with typical antipsychotics or clozapine [Letter]. Lancet 1995;345:456-457. [PubMed: 7853978]

8. Keshavan MS, Haas GL, Kahn CE, Aguilar E, Dick EL, Schooler NR, et al. Superior temporal gyrus and the course of early schizophrenia: progressive, static, or reversible? J Psychiatr Res 1998;32:161167. [PubMed: 9793869]

9. Selemon LD, Lidow MS, Goldman-Rakic PS. Increased volume and glial density in primate prefrontal cortex associated with chronic antipsychotic drug exposure. Biol Psychiatry 1999;46:161-172. [PubMed: 10418690]

10. Hirayasu Y, Shenton ME, Salisbury DF, Kwon JS, Wible CG, Fischer IA, et al. Subgenual cingulate cortex volume in first-episode psychosis. Am J Psychiatry 1999;156:1091-1093. [PubMed: $10401458]$

11. Bilder RM, Wu H, Bogerts B, Degreef G, Ashtari M, Alvir JM, et al. Absence of regional hemispheric volume asymmetries in first-episode schizophrenia. Am J Psychiatry 1994;151:1437-1447. [PubMed: 8092337]

12. DeLisi LE, Hoff AL, Neale C, Kushner M. Asymmetries in the superior temporal lobe in male and female first-episode schizophrenic patients: measures of the planum temporale and superior temporal gyrus by MRI. Schizophr Res 1994;12:19-28. [PubMed: 8018582]

13. DeLisi LE, Hoff AL, Schwartz JE, Shields GW, Halthore SN, Gupta SM, et al. Brain morphology in first-episode schizophrenic-like psychotic patients: a quantitative magnetic resonance imaging study. Biol Psychiatry 1991;29:159-175. [PubMed: 1995085]

14. Gur RE, Maany V, Mozley PD, Swanson C, Bilker W, Gur RC. Subcortical MRI volumes in neuroleptic-naive and treated patients with schizophrenia. Am J Psychiatry 1998;155:1711-1717. [PubMed: 9842780]

15. Nopoulos P, Torres I, Flaum M, Andreasen NC, Ehrhardt JC, Yuh WT. Brain morphology in firstepisode schizophrenia. Am J Psychiatry 1995;152:1721-1723. [PubMed: 8526236]

16. Lawrie SM, Whalley H, Kestelman JN, Abukmeil SS, Byrne M, Hodges A, et al. Magnetic resonance imaging of brain in people at high risk of developing schizophrenia. Lancet 1999;353:30-33. [PubMed: 10023948]

17. Frangou S, Sharma T, Sigmundsson T, Barta P, Pearlson G, Murray RM. The Maudsley Family Study, 4: Normal planum temporale asymmetry in familial schizophrenia: a volumetric MRI study. Br J Psychiatry 1997;170:328-333. [PubMed: 9246250]

18. Staal WG, Hulshoff Pol HE, Schnack HG, Hoogendoorn ML, Jellema K, Kahn RS. Structural brain abnormalities in patients with schizophrenia and their healthy siblings. Am J Psychiatry 2000;157:416-421. [PubMed: 10698818]

19. Cannon TD, Van Erp TGM, Huttunen M, Lönnqvist J, Salonen O, Valanne L, et al. Regional gray matter, white matter, and cerebrospinal fluid distributions in schizophrenic patients, their siblings, and controls. Arch Gen Psychiatry 1998;55:1084-1091. [PubMed: 9862551]

20. Seidman LJ, Faraone SV, Goldstein JM, Goodman JM, Kremen WS, Matsuda G, et al. Reduced subcortical brain volumes in nonpsychotic siblings of schizophrenic patients: a pilot magnetic resonance imaging study. Am J Med Genet 1997;74:507-514. [PubMed: 9342202]

21. Filbey FM, Holcomb J, Nair TR, Christensen JD, Garver DL. Negative symptoms of familial schizophrenia breed true in unstable (vs stable) cerebral-ventricle pedigrees. Schizophr Res 1999;35:15-23. [PubMed: 9988837]

22. Sharma T, Lancaster E, Sigmundsson T, Lewis S, Takei N, Gurling H, et al. Lack of normal pattern of cerebral asymmetry in familial schizophrenic patients and their relatives- the Maudsley Family Study. Schizophr Res 1999;40:111-120. [PubMed: 10593451]

23. Chua SE, Sharma T, Takei N, Murray RM, Woodruff PW. A magnetic resonance imaging study of corpus callosum size in familial schizophrenic subjects, their relatives, and normal controls. Schizophr Res 2000;41:397-403. [PubMed: 10728717]

24. Kendler KS, Walsh D. Schizotypal personality disorder in parents and the risk for schizophrenia in siblings. Schizophr Bull 1995;21:47-52. [PubMed: 7770740]

25. Kendler KS, Neale MC, Walsh D. Evaluating the spectrum concept of schizophrenia in the Roscommon Family Study. Am J Psychiatry 1995;152:749-754. [PubMed: 7726315] 
26. Kendler KS, McGuire M, Gruenberg AM, Walsh D. Schizotypal symptoms and signs in the Roscommon Family Study: their factor structure and familial relationship with psychotic and affective disorders. Arch Gen Psychiatry 1995;52:296-303. [PubMed: 7702446]

27. Kendler KS, McGuire M, Gruenberg AM, O’Hare A, Spellman M, Walsh D. The Roscommon Family Study, I: Methods, diagnosis of probands, and risk of schizophrenia in relatives. Arch Gen Psychiatry 1993;50:527-540. [PubMed: 8317947]

28. Tsuang MT, Stone WS, Faraone SV. Schizophrenia: a review of genetic studies. Harvard Rev Psychiatry 1999;7:185-207.

29. Kety, SS.; Rosenthal, D.; Wender, PH.; Schulsinger, F. The types and prevalence of mental illness in the biological and adoptive families of adopted schizophrenics; Presented at the Second Research Conference of the Foundations' Fund for Research in Psychiatry, Dorado, Puerto Rico; 1967 June/ July.

30. Kendler KS, McGuire M, Gruenberg AM, O'Hare A, Spellman M, Walsh D. The Roscommon Family Study, III: Schizophrenia-related personality disorders in relatives. Arch Gen Psychiatry 1993;50:781-788. [PubMed: 8215802]

31. Siever LJ, Silverman JM, Horvath TB, Klar H, Coccaro E, Keefe RS, et al. Increased morbid risk for schizophrenia-related disorders in relatives of schizotypal personality disordered patients. Arch Gen Psychiatry 1990;47:634-640. [PubMed: 2360857]

32. Siever LJ. Biologic factors in schizotypal personal disorders. Acta Psychiatr Scand Suppl 1994;384:45-50. [PubMed: 7879643]

33. Siever LJ, Amin F, Coccaro EF, Trestman R, Silverman J, Horvath TB, et al. CSF homovanillic acid in schizotypal personality disorder. Am J Psychiatry 1993;150:149-151. [PubMed: 8417559]

34. Siever LJ, Amin F, Coccaro EF, Bernstein D, Kavoussi RJ, Kalus O, et al. Plasma homovanillic acid in schizotypal personality disorder. Am J Psychiatry 1991;148:1246-1248. [PubMed: 1883008]

35. Siever LJ, Keefe R, Bernstein DP, Coccaro EF, Klar HM, Zemishlany Z, et al. Eye tracking impairment in clinically identified patients with schizotypal personality disorder. Am J Psychiatry 1990;147:740-745. [PubMed: 2343917]

36. Siever LJ, Friedman L, Moskowitz J, Mitropoulou V, Keefe R, Roitman SL, et al. Eye movement impairment and schizotypal psychopathology. Am J Psychiatry 1994;151:1209-1215. [PubMed: 8037257]

37. Clementz BA, Reid SA, McDowell JE, Cadenhead KS. Abnormality of smooth pursuit eye movement initiation: specificity to the schizophrenia spectrum? Psychophysiology 1995;32:130-134. [PubMed: 7630977]

38. Thaker GK, Cassady S, Adami H, Moran M, Ross DE. Eye movements in spectrum personality disorders: comparison of community subjects and relatives of schizophrenic patients. Am J Psychiatry 1996;153:362-368. [PubMed: 8610823]

39. Cadenhead KS, Geyer MA, Braff DL. Impaired startle prepulse inhibition and habituation in patients with schizotypal personality disorder. Am J Psychiatry 1993;150:1862-1867. [PubMed: 8238643]

40. Trestman RL, Keefe RS, Mitropoulou V, Harvey PD, DeVegvar ML, Lees-Roitman S, et al. Cognitive function and biological correlates of cognitive performance in schizotypal personality disorder. Psychiatry Res 1995;59:127-136. [PubMed: 8771227]

41. Kinney DK, Holzman PS, Jacobsen B, Jansson L, Faber B, Hildebrand W, et al. Thought disorder in schizophrenic and control adoptees and their relatives. Arch Gen Psychiatry 1997;54:475-479. [PubMed: 9152101]

42. Voglmaier M, Seidman L, Salisbury D, McCarley R. Neuropsychological dysfunction in schizotypal personality disorder: a profile analysis. Biol Psychiatry 1997;41:530-540. [PubMed: 9046985]

43. Voglmaier MM, Seidman LJ, Niznikiewicz MA, Dickey CC, Shenton ME, McCarley RW. Verbal and nonverbal neuropsychological test performance in subjects with schizotypal personality disorder. Am J Psychiatry 2000;157:787-793. [PubMed: 10784473]

44. Salisbury DF, Voglmaier MM, Seidman LJ, McCarley RW. Topographic abnormalities of P3 in schizotypal personality disorder. Biol Psychiatry 1996;40:165-172. [PubMed: 8830949]

45. Niznikiewicz MA, Voglmaier M, Shenton ME, Seidman LJ, Dickey CC, Rhoads R, et al. Electrophysiological correlates of language processing in schizotypal personality disorder. Am J Psychiatry 1999;156:1052-1058. [PubMed: 10401451] 
46. Niznikiewicz MA, O’Donnell BF, Nestor PG, Smith L, Law S, Karapelou M, et al. ERP assessment of visual and auditory language processing in schizophrenia. J Abnorm Psychol 1997;106:85-94. [PubMed: 9103720]

47. Cadenhead KS, Light GA, Geyer MA, Braff DL. Sensory gating deficits assessed by the P50 eventrelated potential in subjects with schizotypal personality disorder. Am J Psychiatry 2000;157:55-59. [PubMed: 10618013]

48. Trestman RL, Horvath T, Kalus O, Peterson AE, Coccaro E, Mitropoulou V, et al. Event-related potentials in schizotypal personality disorder. J Neuropsychiatry Clin Neurosci 1996;8:33-40. [PubMed: 8845699]

49. Downhill JE Jr, Buchsbaum MS, Wei T, Spiegel-Cohen J, Hazlett EA, Haznedar MM, et al. Shape and size of the corpus callosum in schizophrenia and schizotypal personality disorder. Schizophr Res 2000;42:193-208. [PubMed: 10785578]

50. Buchsbaum MS, Yang S, Hazlett E, Siegel BV Jr, Germans M, Haznedar M, et al. Ventricular volume and asymmetry in schizotypal personality disorder and schizophrenia assessed with magnetic resonance imaging. Schizophr Res 1997;27:45-53. [PubMed: 9373894]

51. Hazlett EA, Buchsbaum MS, Byne W, Wei TC, Spiegel-Cohen J, Geneve C, et al. Three-dimensional analysis with MRI and PET of the size, shape, and function of the thalamus in the schizophrenia spectrum. Am J Psychiatry 1999;156:1190-1199. [PubMed: 10450259]

52. Byne W, Buchsbaum MS, Kemether E, Hazlett EA, Shinwari A, Mitropoulou V, et al. Magnetic resonance imaging of the thalamic mediodorsal nucleus and pulvinar in schizophrenia and schizotypal personality disorder. Arch Gen Psychiatry 2001;58:133-140. [PubMed: 11177115]

53. Kwon JS, Shenton ME, Hirayasu Y, Salisbury DF, Fischer IA, Dickey CC, et al. MRI study of cavum septi pellucidi in schizophrenia, affective disorder, and schizotypal personality disorder. Am J Psychiatry 1998;155:509-515. [PubMed: 9545997]

54. Dickey CC, McCarley RW, Voglmaier MM, Niznikiewicz MA, Seidman LJ, Hirayasu Y, et al. Schizotypal personality disorder and MRI abnormalities of temporal lobe gray matter. Biol Psychiatry 1999;45:1393-1402. [PubMed: 10356620]

55. Dickey CC, Shenton ME, Hirayasu Y, Fischer I, Voglmaier MM, Niznikiewicz MA, et al. Large CSF volume not attributable to ventricular volume in schizotypal personality disorder. Am J Psychiatry 2000;157:48-54. [PubMed: 10618012]

56. Cannon TD, Raine A, Herman TM, Mednick SA, Schulsinger F, Moore M. Third ventricle enlargement and lower heart rate levels in a high-risk sample. Psychophysiology 1992;29:294-301. [PubMed: 1626039]

57. Cannon TD, Mednick SA, Parnas J, Schulsinger F, Praestholm J, Vestergaard A. Developmental brain abnormalities in the offspring of schizophrenic mothers, II: Structural brain characteristics of schizophrenia and schizotypal personality disorder. Arch Gen Psychiatry 1994;51:955-962. [PubMed: 7979884]

58. McGlashan TH. Schizotypal personality disorder: Chestnut Lodge follow-up study, VI: Long-term follow-up perspectives. Arch Gen Psychiatry 1986;43:329-334. [PubMed: 3954556]

59. Mesulam, MM., editor. Principles of behavioral and cognitive neurology. 2nd ed. Oxford, England: Oxford University Press; 2000.

60. Andreasen NC, Arndt S, Swayze V II, Cizadlo T, Flaum M, O'Leary D, et al. Thalamic abnormalities in schizophrenia visualized through magnetic resonance image averaging. Science 1994;266:294298. [PubMed: 7939669]

61. Nolte, J. The human brain: an introduction to its functional anatomy. 4th ed. St. Louis: Mosby; 1999.

62. Gruzelier, JH. Hemispheric imbalance: syndromes of schizophrenia, premorbid personality, and neurodevelopmental influences. In: Steinhauer, S.; Gruzelier, J.; Zubin, J., editors. Handbook of schizophrenia, vol 5: Neuropsychology, psychophysiology, and information processing. New York: Elsevier; 1991. p. 599-650.

63. Barta PE, Pearlson GD, Powers RE, Richards SS, Tune LE. Auditory hallucinations and smaller superior temporal gyral volume in schizophrenia. Am J Psychiatry 1990;147:1457-1462. [PubMed: 2221156]

Harv Rev Psychiatry. Author manuscript; available in PMC 2010 April 13. 
64. Marsh L, Harris D, Lim KO, Beal M, Hoff AL, Minn K, et al. Structural magnetic resonance imaging abnormalities in men with severe chronic schizophrenia and an early age at clinical onset. Arch Gen Psychiatry 1997;54:1104-1112. [PubMed: 9400346]

65. Menon RR, Barta PE, Aylward EH, Richards SS, Vaughn DD, Tien AY, et al. Posterior superior temporal gyrus in schizophrenia: grey matter changes and clinical correlates. Schizophr Res 1995;16:127-135. [PubMed: 7577766]

66. Vita A, Dieci M, Giobbio GM, Caputo A, Ghiringhelli L, Comazzi M, et al. Language and thought disorder in schizophrenia: brain morphological correlates. Schizophr Res 1995;15:243-251. [PubMed: 7632621]

67. Nestor PG, Shenton ME, McCarley RW, Haimson J, Smith RS, O’Donnell B, et al. Neuropsychological correlates of MRI temporal lobe abnormalities in schizophrenia. Am J Psychiatry 1993;150:1849-1855. [PubMed: 8238641]

68. Sarter M, Markowitsch HJ. The amygdala's role in human mnemonic processing. Cortex 1985;21:724. [PubMed: 3886288]

69. Whalen PJ, Rauch SL, Etcoff NL, McInerney SC, Lee MB, Jenike MA. Masked presentations of emotional facial expressions modulate amygdala activity without explicit knowledge. J Neurosci 1998;18:411-418. [PubMed: 9412517]

70. Shenton ME, Kikinis R, Jolesz FA, Pollak SD, LeMay M, Wible CG, et al. Abnormalities of the left temporal lobe and thought disorder in schizophrenia: a quantitative magnetic resonance imaging study. N Engl J Med 1992;327:604-612. [PubMed: 1640954]

71. Hirayasu Y, Shenton ME, Salisbury DF, Dickey CC, Fischer IA, Mazzoni P, et al. Lower left temporal lobe MRI volumes in patients with first-episode schizophrenia compared with psychotic patients with first-episode affective disorder and normal subjects. Am J Psychiatry 1998;155:1384-1391. [PubMed: 9766770]

72. Dickey CC, Shenton ME, Faraone S, Niznikiewicz MA, Voglmaier MM, Seidman LJ, et al. Reduced left Heschl's gyrus volume in schizotypal personality disorder [Abstract]. Biol Psychiatry 2000;47 $13-4 \mathrm{~S}$.

73. McDonald B, Highley JR, Walker MA, Herron BM, Cooper SJ, Esiri MM, et al. Anomalous asymmetry of fusiform and parahippocampal gyrus gray matter in schizophrenia: a postmortem study. Am J Psychiatry 2000;157:40-47. [PubMed: 10618011]

74. Siever LJ, Rotter M, Losonczy M, Guo SL, Mitropoulou V, Trestman R, et al. Lateral ventricular enlargement in schizotypal personality disorder. Psychiatry Res 1995;57:109-118. [PubMed: 7480378]

75. Raine A, Sheard C, Reynolds GP, Lencz T. Pre-frontal structural and functional deficits associated with individual differences in schizotypal personality. Schizophr Res 1992;7:237-247. [PubMed: 1390403]

76. Gotz, M. The psychiatric consequences of sex chromosome abnormalities: a cohort study [Unpublished master's dissertation]. Edinburgh: University of Edinburgh; 1996.

77. Warwick MM, Doody GA, Lawrie SM, Kestelman JN, Best JJ, Johnstone EC. Volumetric magnetic resonance imaging study of the brain in subjects with sex chromosome aneuploidies. J Neurol Neurosurg Psychiatry 1999;66:628-632. [PubMed: 10209175]

78. Hendren RL, Hodde-Vargas J, Yeo RA, Vargas LA, Brooks WM, Ford C. Neuropsychophysiological study of children at risk for schizophrenia: a preliminary report. J Am Acad Child Adolesc Psychiatry 1995;34:1284-1291. [PubMed: 7592265]

79. DeLisi LE, Sakuma M, Ge S, Kushner M. Association of brain structural change with heterogeneous course of schizophrenia from early childhood through five years subsequent to a first hospitalization. Psychiatry Res 1998;84:75-88. [PubMed: 10710165]

80. Nair TR, Christensen JD, Kingsbury SJ, Kumar NG, Terry WM, Garver DL. Progression of cerebroventricular enlargement and the subtyping of schizophrenia. Psychiatry Res 1997;74:141150. [PubMed: 9255859]

81. Kurokawa K, Nakamura K, Sumiyoshi T, Hagino H, Yotsutsuji T, Yamashita I, et al. Ventricular enlargement in schizophrenia spectrum patients with prodromal symptoms of obsessive-compulsive disorder. Psychiatry Res 2000;99:83-91. [PubMed: 10963984] 
82. Shihabuddin L, Silverman JM, Buchsbaum MS, Siever LJ, Luu C, Germans MK, et al. Ventricular enlargement associated with linkage marker for schizophrenia-related disorders in one pedigree. Mol Psychiatry 1996;1:215-222. [PubMed: 9118345]

83. Silverman JM, Smith CJ, Guo SL, Mohs RC, Siever LJ, Davis KL. Lateral ventricular enlargement in schizophrenic probands and their siblings with schizophrenia-related disorders. Biol Psychiatry 1998;43:97-106. [PubMed: 9474442]

84. Schulsinger F, Parnas J, Petersen ET, Schulsinger H, Teasdale TW, Mednick SA, et al. Cerebral ventricular size in the offspring of schizophrenic mothers: a preliminary study. Arch Gen Psychiatry 1984;41:602-606. [PubMed: 6732420] 
TABLE 1

\section{Morphological Studies of SPD}

\begin{tabular}{|c|c|c|c|c|}
\hline Study & Subjects & Regions examined/measures & Findings & Comments \\
\hline Schulsinger et al. ${ }^{84}$ & $\begin{array}{l}33 \text { offspring of } \\
\text { mothers with SZ ( } 11 \\
\text { with borderline SZ } \\
\text { [probably SPD], } 8 \\
\text { with SZ, } 14 \text { mentally } \\
\text { healthy) }\end{array}$ & $\begin{array}{l}\text { Lateral ventricle, third ventricle, } \\
\text { VBR }\end{array}$ & $\begin{array}{l}\text { Subjects with SZ had } \\
\text { largest ventricles, } \\
\text { followed by mentally } \\
\text { healthy subjects; } \\
\text { those with borderline } \\
\text { SZ had the smallest }\end{array}$ & $\begin{array}{l}\text { CT study; each measurement } \\
\text { performed on } 1 \text { slice. Subjects with } \\
\text { borderline SZ had fewer obstetrical } \\
\text { complications than did those with } \\
\text { SZ. }\end{array}$ \\
\hline Cannon et al. 57 & $\begin{array}{l}34 \text { offspring of } \\
\text { mothers with SZ (12 } \\
\text { with SPD, } 7 \text { with SZ, } \\
15 \text { unaffected) }\end{array}$ & $\begin{array}{l}\text { Maximum width of sylvian } \\
\text { fissure, width of anterior } \\
\text { interhemi spheric fissure, mean } \\
\text { width of } 3 \text { broadest cortical sulci, } \\
\text { width of third ventricle, area of } \\
\text { lateral ventricle, VBR, } \\
\text { qualitative assessment of } \\
\text { cerebellar vermis }\end{array}$ & $\begin{array}{l}\text { Enlarged third } \\
\text { ventricles correlated } \\
\text { with lower heart rate } \\
18 \text { y previously }\end{array}$ & $\begin{array}{l}\text { CT study; each measurement } \\
\text { performed on } 1 \text { slice, sometimes } \\
\text { using calipers. Sample overlaps } \\
\text { with Schulsinger et al. }{ }^{84} \text { Authors } \\
\text { also measured heart rate on } \\
\text { enrollment in the study, } 18 \text { y } \\
\text { previously. The } 3 \text { groups were not } \\
\text { compared on CT measures. }\end{array}$ \\
\hline Raine et al. 75 & $\begin{array}{l}17 \text { with schizotypal } \\
\text { features, but not SPD }\end{array}$ & Prefrontal cortex, temporal lobe & $\begin{array}{l}\text { High scores on } \\
\text { schizotypy scales } \\
\text { correlated with } \\
\text { reduced left prefrontal } \\
\text { area and with high left } \\
\text { and right } \\
\text { prefrontal:temporal } \\
\text { lobe area ratios }\end{array}$ & $\begin{array}{l}\text { MRI study, } 0.15 \text {-T magnet; } 12 \\
\text { slices, } 10 \mathrm{~mm} \text { thick, with single } \\
\text { slices used for measures of } \\
\text { prefrontal and temporal cortex }\end{array}$ \\
\hline Cannon et al. 57 & $\begin{array}{l}126 \text { offspring of } \\
\text { mothers with SZ ( } 31 \\
\text { with SPD, } 17 \text { with } \\
\text { SZ, } 33 \text { with another } \\
\text { diagnosis, } 45 \text { with no } \\
\text { diagnosis) and } 77 \\
\text { offspring of NC } \\
\text { mothers ( } 1 \text { with SZ, } 4 \\
\text { with SPD, } 26 \text { with } \\
\text { another diagnosis, } 46 \\
\text { with no diagnosis) }\end{array}$ & $\begin{array}{l}\text { Ventricles and sulci, VBR, } \\
\text { sulcus:brain ratio, temporal and } \\
\text { frontal fissures, lateral ventricles }\end{array}$ & $\begin{array}{l}\text { Offspring of mothers } \\
\text { with SZ who had SZ } \\
\text { or SPD showed larger } \\
\text { sulci than did any } \\
\text { other group; offspring } \\
\text { of mothers with SZ } \\
\text { who had SZ had larger } \\
\text { ventricles than did } \\
\text { any other group }\end{array}$ & $\begin{array}{l}\text { CT study; } 13 \text { slices, } 8 \mathrm{~mm} \text { thick. } \\
\text { The sample overlaps in part with } \\
\text { those of Schulsinger et al. }{ }^{84} \text { and } \\
\text { Cannon et al. } 56\end{array}$ \\
\hline Hendren et al. 78 & $\begin{array}{l}25 \text { children aged } 8- \\
12 \text { y }(12 \text { with } \\
\text { symptoms of SPD or } \\
\text { early-onset SZ, } 13 \\
\text { NCs }\end{array}$ & $\begin{array}{l}\text { Amygdala, hippocampus, part of } \\
\text { temporal cortex (slices on which } \\
\text { amygdala and hippocampus } \\
\text { could be visualized), corpus } \\
\text { callosum area, cerebellum area, } \\
\text { frontal lobe area (on midsagittal } \\
\text { slice), lateral ventricle, third } \\
\text { ventricle, temporal horn }\end{array}$ & $\begin{array}{l}\text { Children with } \\
\text { symptoms of SPD or } \\
\text { SZ had reduced } \\
\text { amygdala and } \\
\text { temporal cortex } \\
\text { volumes, callosal area }\end{array}$ & $\begin{array}{l}\text { MRI study, } 1.5 \text {-T magnet; area } \\
\text { measures were performed on } 1 \\
\text { slice. MRS data were also reported } \\
\text { for } 9 \text { subjects and } 8 \text { controls. Poor } \\
\text { complex verbal memory was seen } \\
\text { in children with symptoms of SPD } \\
\text { or SZ. }\end{array}$ \\
\hline Siever et al. ${ }^{74}$ & $\begin{array}{l}36 \text { with SPD, } 23 \text { with } \\
\text { other personality } \\
\text { disorders, } 133 \text { with } \\
\text { SZ, } 42 \mathrm{NCs}\end{array}$ & $\begin{array}{l}\text { VBR, frontal and posterior horns } \\
\text { of lateral ventricle, third } \\
\text { ventricle }\end{array}$ & $\begin{array}{l}\text { VBRs of subjects with } \\
\text { SPD were higher than } \\
\text { those of subjects with } \\
\text { other personality } \\
\text { disorders and were } \\
\text { intermediate between } \\
\text { (but not significantly } \\
\text { different from) VBRs } \\
\text { of NCs and those of } \\
\text { subjects with SZ }\end{array}$ & $\begin{array}{l}\text { CT study ( } 2 \text { different scanners } \\
\text { used); slices } 0.8-1.0 \mathrm{~cm} \text { thick, } \\
\text { depending on scanner. Some of the } \\
\text { subjects with SPD had been } \\
\text { exposed to neuroleptics. }\end{array}$ \\
\hline Shihabuddin et al. 82 & $\begin{array}{l}11 \text { individuals from a } \\
\text { single pedigree ( } 2 \\
\text { with SPD, } 3 \text { with SZ, } \\
6 \text { unaffected) }\end{array}$ & $\begin{array}{l}\text { Lateral ventricles, VBR, anterior } \\
\text { horn, temporal horn, measure of } \\
\text { sulcal CSF by brain region }\end{array}$ & $\begin{array}{l}\text { Affected subjects plus } \\
1 \text { unaffected subject } \\
\text { (all of whom carried a } \\
\text { genetic marker for } \\
\text { schizophrenia) had } \\
\text { larger ventricles, a } \\
\text { higher VBR, and } \\
\text { larger CSF volumes in } \\
\text { frontal and parietal } \\
\text { regions than did the } 5 \\
\text { subjects not carrying } \\
\text { the marker }\end{array}$ & $\begin{array}{l}\text { CT study; slices } 8 \mathrm{~mm} \text { thick. Data } \\
\text { for subjects with SPD were not } \\
\text { analyzed separately. }\end{array}$ \\
\hline
\end{tabular}




\begin{tabular}{|c|c|c|c|c|}
\hline Study & Subjects & Regions examined/measures & Findings & Comments \\
\hline Buchsbaum et al. 50 & $\begin{array}{l}12 \text { with SPD, } 11 \text { with } \\
\text { SZ, } 23 \text { NCs }\end{array}$ & $\begin{array}{l}\text { Lateral ventricles, anterior horn, } \\
\text { temporal horn }\end{array}$ & $\begin{array}{l}\text { Left anterior and } \\
\text { temporal horn } \\
\text { volumes in subjects } \\
\text { with SPD were } \\
\text { between those of NCs } \\
\text { and those of subjects } \\
\text { with SZ, differing } \\
\text { significantly from the } \\
\text { latter }\end{array}$ & $\begin{array}{l}\text { MRI study, } 1.5 \text {-T magnet; }{ }^{*} \text { slices } \\
1.2 \mathrm{~mm} \text { thick }\end{array}$ \\
\hline Kwon et al. 53 & $\begin{array}{l}16 \text { with SPD, } 5 \text { with } \\
\text { subthreshold SPD, }{ }^{\dagger} \\
15 \text { with chronic SZ, } \\
15 \text { with first- episode } \\
\text { SZ, } 16 \text { with first- } \\
\text { episode psychotic } \\
\text { affective disorder, } 46 \\
\text { NCs }\end{array}$ & $\begin{array}{l}\text { Presence of large cavum septi } \\
\text { pellucidi }\end{array}$ & $\begin{array}{l}\text { A large cavum septi } \\
\text { pellucidi was more } \\
\text { common in subjects } \\
\text { with SZ than in NCs } \\
\text { (found in } 27.3 \% \text { of } \\
\text { subjects with SPD, } \\
35 \% \text { of those with SZ, } \\
25 \% \text { of those with } \\
\text { psychotic affective } \\
\text { disorder, and } 13 \% \text { of } \\
\text { NCs) }\end{array}$ & $\begin{array}{l}\text { MRI study, } 1.5-\mathrm{T} \text { magnet. } \\
\text { Appearance of cavum was } \\
\text { evaluated on } 1.5-\mathrm{mm} \text { slices. }\end{array}$ \\
\hline Silverman et al. 83 & $\begin{array}{l}11 \text { with SPD (at least } \\
4 \text { criteria) } \neq 42 \text { with } \\
\text { SZ, } 6 \text { with SCA, } 56 \\
\text { unaffected relatives, } \\
22 \text { NCs }\end{array}$ & VBR & $\begin{array}{l}\text { No difference was } \\
\text { seen between subjects } \\
\text { with SPD and those } \\
\text { with SZ; subjects with } \\
\text { SZ and SPD had } \\
\text { higher VBRs than did } \\
\text { their unaffected } \\
\text { relatives }\end{array}$ & $\begin{array}{l}\text { CT study; slices } 8.0 \mathrm{~mm} \text { thick. One } \\
\text { slice used for comparison. }\end{array}$ \\
\hline Dickey et al. ${ }^{54}$ & $\begin{array}{l}16 \text { with SPD, } 5 \text { with } \\
\text { subthreshold SPD, }{ }^{\dagger} \\
14 \text { NCs }\end{array}$ & $\begin{array}{l}\text { Superior temporal gyrus, } \\
\text { amygdala, hippocampus, } \\
\text { parahippocampus }\end{array}$ & $\begin{array}{l}\text { Subjects with SPD } \\
\text { showed reduced } \\
\text { superior temporal } \\
\text { gyrus volume and } \\
\text { differences in } \\
\text { parahippocampal } \\
\text { asymmetry compared } \\
\text { with NCs }\end{array}$ & $\begin{array}{l}\text { MRI study; } 1.5 \text {-T magnet; slices } 1.5 \\
\text { mm thick. Sample overlaps with } \\
\text { that of Kwon et al. } 53\end{array}$ \\
\hline Hazlett et al ${ }^{51}$ & $\begin{array}{l}13 \text { with SPD, } 27 \text { with } \\
\text { SZ, } 32 \text { NCs }\end{array}$ & $\begin{array}{l}\text { Thalamic volume, } \\
\text { thalamus:brain ratio }\end{array}$ & $\begin{array}{l}\text { No differences were } \\
\text { seen in thalamic } \\
\text { volume; shape } \\
\text { analysis suggested } \\
\text { fewer pixels in the } \\
\text { right mediodorsal } \\
\text { nucleus in subjects } \\
\text { with SPD than in NCs, } \\
\text { and fewer pixels in the } \\
\text { left anterior regions in } \\
\text { subjects with SZ than } \\
\text { in NCs }\end{array}$ & $\begin{array}{l}\text { MRI study, } 1.5-T \text { magnet; }{ }^{+} \text {slices } \\
1.2 \text { mm thick. Study also included } \\
\text { a PET component, which showed } \\
\text { no difference in thalamic } \\
\text { metabolism between subjects with } \\
\text { SPD and NCs (although the } \\
\text { subjects with SZ had lower bilateral } \\
\text { metabolism in the mediodorsal } \\
\text { nucleus of the thalamus than did } \\
\text { subjects with SPD or NCs). }\end{array}$ \\
\hline Warwick et al. ${ }^{77}$ & $\begin{array}{l}32 \text { with sex } \\
\text { chromosome } \\
\text { aneuploidies }(11 \\
\text { with } 47 \text { XXX, } 10 \\
\text { with } 47 \text { XYY, } 10 \\
\text { with } 47 \text { XXY), } 38 \\
\text { NCs } \$\end{array}$ & $\begin{array}{l}\text { Whole brain, } R \text { and } L \text { prefrontal } \\
\text { lobes, } R \text { and } L \text { temporal lobes, } R \\
\text { and } L \text { lentiform nuclei, } R \text { and } L \\
\text { caudate nuclei, } R \text { and } L \\
\text { thalamus, } R \text { and } L \\
\text { amygdalohippocampal complex, } \\
\text { lateral ventricles, third and fourth } \\
\text { ventricles }\end{array}$ & $\begin{array}{l}\text { SIS scores for } \\
\text { introversion, magical } \\
\text { thinking, and } \\
\text { impulsivity did not } \\
\text { correlate with whole } \\
\text { brain volumes for the } \\
\text { XXX group: females } \\
\text { with XXX had } \\
\text { smaller whole brains } \\
\text { than did female NCs, } \\
\text { males with XXY had } \\
\text { smaller whole brains } \\
\text { and larger lateral } \\
\text { ventricles than did } \\
\text { male NCs. }\end{array}$ & $\begin{array}{l}\text { MRI study, 1.0-T magnet. Study } \\
\text { based on reports of increased } \\
\text { incidence of schizotypal traits in } \\
\text { persons with sex chromosome } \\
\text { aneuploidies. Data for subjects } \\
\text { scoring high on the SIS were not } \\
\text { analyzed separately. }\end{array}$ \\
\hline Dickey et al. 55 & 16 with SPD, 14 NCs & $\begin{array}{l}\text { Lateral ventricles, temporal } \\
\text { horn, total CSF, cortical gray } \\
\text { matter, total gray matter, white } \\
\text { matter }\end{array}$ & $\begin{array}{l}\text { Subjects with SPD } \\
\text { had greater CSF } \\
\text { volumes (but not } \\
\text { ventricular volumes) } \\
\text { than did NCs; a trend } \\
\text { was seen toward } \\
\text { reduced cortical gray }\end{array}$ & $\begin{array}{l}\text { MRI study, } 1.5 \text {-T magnet; slices } 1.5 \\
\text { mm thick. Sample overlaps with } \\
\text { those of Kwon et al. } 53 \text { and Dickey } \\
\text { et al. } 54\end{array}$ \\
\hline
\end{tabular}




\begin{tabular}{|c|c|c|c|c|}
\hline Study & Subjects & Regions examined/measures & Findings & Comments \\
\hline & & & $\begin{array}{l}\text { matter volumes in } \\
\text { subjects with SPD } \\
\text { compared with NCs }\end{array}$ & \\
\hline Downhill et al. ${ }^{49}$ & $\begin{array}{l}13 \text { with SPD, } 27 \text { with } \\
\text { SZ, } 30 \mathrm{NCs}\end{array}$ & $\begin{array}{l}\text { Shape and size of corpus } \\
\text { callosum; volume of lateral } \\
\text { ventricles and anterior and } \\
\text { temporal horns }\end{array}$ & $\begin{array}{l}\text { The genu was larger in } \\
\text { subjects with SPD } \\
\text { than in those with SZ } \\
\text { or NCs; a region of the } \\
\text { callosum just } \\
\text { posterior to the genu } \\
\text { was smaller in } \\
\text { subjects with SPD } \\
\text { than in those with SZ } \\
\text { or NCs; the genu and } \\
\text { splenium together } \\
\text { were smaller in } \\
\text { subjects with SZ than } \\
\text { in NCs; no correlation } \\
\text { was seen between } \\
\text { corpus and ventricular } \\
\text { measures in subjects } \\
\text { with SPD }\end{array}$ & $\begin{array}{l}\text { MRI study, } 1.5 \text {-T magnet; } ; \text { slices } \\
1.2 \text { mm thick. Sample overlaps, in } \\
\text { part, with that of Buchsbaum et al. } \\
50\end{array}$ \\
\hline Kurokawa et al. ${ }^{81}$ & $\begin{array}{l}4 \text { with SPD, } 4 \text { with } \\
\text { SZ, } 7 \text { with OCD, } 1 \\
\text { with BDD, } 14 \text { NCs }\end{array}$ & $\begin{array}{l}\text { Lateral ventricles, inferior horn, } \\
\text { third ventricle, VBR on } 3 \text { slices }\end{array}$ & $\begin{array}{l}\text { The inferior horn was } \\
\text { larger and the VBR } \\
\text { was higher in subjects } \\
\text { with SPD or SZ than } \\
\text { in those with OCD or } \\
\text { NCs; the third } \\
\text { ventricle was larger } \\
\text { and the VBR was } \\
\text { higher in subjects } \\
\text { with SPD/SZ than in } \\
\text { those with OCD }\end{array}$ & $\begin{array}{l}\text { MRI study, } 1.5 \text {-T magnet; slices } 1.0 \\
\text { mm thick; measurements were } \\
\text { performed on only } 3 \text { slices. All } 4 \\
\text { subjects with SPD were treated } \\
\text { with neuroleptics (type } \\
\text { unspecified), and } 2 \text { were treated } \\
\text { with clomipramine. Data for } \\
\text { subjects with SPD were not } \\
\text { analyzed separately. }\end{array}$ \\
\hline Byne et al. 52 & $\begin{array}{l}12 \text { with SPD, } 12 \text { with } \\
\text { SZ, } 12 \text { NCs }\end{array}$ & $\begin{array}{l}\text { Thalamus, pulvinar, mediodorsal } \\
\text { nucleus of thalamus }\end{array}$ & $\begin{array}{l}\text { No differences were } \\
\text { seen in the thalamus; } \\
\text { pulvinar volumes and } \\
\text { combined pulvinar/ } \\
\text { mediodorsal nucleus } \\
\text { volumes were smaller } \\
\text { in subjects with SPD } \\
\text { or SZ than in NCs; the } \\
\text { mediodorsal nucleus } \\
\text { was smaller in } \\
\text { subjects with SZ than } \\
\text { in NCs }\end{array}$ & $\begin{array}{l}\text { MRI study; } 1.5 \text {-T magnet; slices } 1.2 \\
\text { mm thick. Subsample of Hazlett et } \\
\text { al. } 51\end{array}$ \\
\hline
\end{tabular}

$B D D$, body dysmorphic disorder; $C S F$, cerebrospinal fluid; $C T$, computerized tomography; $M R I$, magnetic resonance imaging; $M R S$, magnetic resonance spectroscopy; $N C$, normal control; $N O S$, not otherwise specified; $O C D$, obsessive-compulsive disorder; $P D$, personality disorder; $P E T$, positron emission tomography; SIS, Structured Interview for Schizotypy; SPD, schizotypal personality disorder; SZ, schizophrenia; SZA, schizoaffective disorder; $V B R$, ventricle:brain ratio.

GE Signa $5 \mathrm{X}$ reported; we assume this was a 1.5-T system.

${ }^{\dagger}$ Subjects met either three or four of the nine criteria for diagnosis.

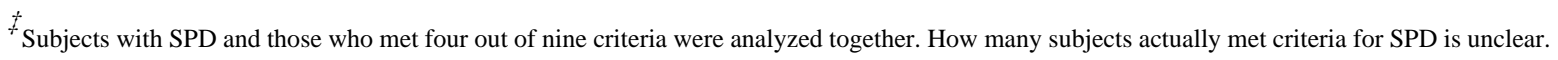
$\S_{\text {An unclear number of subjects scored high on the SIS. }}$ 
TABLE 2

Comparison of Morphological Abnormalities in SPD with Those in First-Episode Schizophrenia and FirstEpisode Psychotic Affective Disorder

\begin{tabular}{llll}
\hline Abnormality & SPD & FE SZ & FE AFF \\
\hline Sulcal CSF increase & Yes & Yes & No \\
Cortical gray matter decrease & Trend & Left & No \\
Left STG gray matter decrease & Yes & Yes & No \\
Posterior STG subdivisions decrease & & & \\
$\quad$ Heschl's gyrus & Yes & Yes & No \\
Planum temporale & No & Yes & No \\
Medial temporal lobe subdivisions decrease & & & \\
Amygdala & No & Yes & Yes \\
Hippocampus & No & Yes & Yes \\
Parahippocampus & Asymmetry & Yes & Yes \\
Large cavum septi pellucidi & Yes & Yes & Yes \\
\hline
\end{tabular}

$A F F$, psychotic affective disorder; $C S F$, cerebrospinal fluid; $F E$, first episode; $S P D$, schizotypal personality disorder; $S T G$, superior temporal gyrus; $S Z$, schizophrenia. 